\title{
Recenzja: Ikram Masmoudi. 2015. War and Occupation in Iraqi Fiction. Edinburgh: Edinburgh University Press, 248 stron.
}

Badacze współczesnej literatury irackiej podkreślają, że w dyskusji dotyczącej sytuacji w Iraku w kilku ostatnich dekadach, zdeterminowanej przez brutalne autorytarne rządy i następujące po sobie wojny, niejednokrotnie nie uwzględnia się tego, co mają do powiedzenia iraccy intelektualiści za pośrednictwem tworzonych przez siebie utworów beletrystycznych, w finezyjny sposób ukazujących i analizujących otaczającą ich rzeczywistość (Ghazoul 2009: 233). Pogląd ten podziela Ikram Masmoudi, autorka War and Occupation in Iraqi Fiction, która we wprowadzeniu do tej książki wyjaśnia, że iracka fikcja literacka tworzona po upadku reżimu Saddama Husajna w 2003 roku, uwolniona od krępującego jarzma cenzury:

przedstawia brakujący fragment puzzli wiedzy o irackim społeczeństwie i jego kulturze. Stosunek świata do Iraku został zdominowany przez wojskowe, polityczne i akademickie dyskursy Zachodu na temat tego kraju; istnieje znacząca luka w tej wiedzy, która może zostać wypełniona poprzez świadectwa irackich pisarzy, opowiedziane ich własnymi głosami i, aż do chwili obecnej, jedynie w ich języku; oferujące ich własne punkty widzenia na wydarzenia, które ukształtowały ich historię i zmieniły ich życie (Masmoudi 2015: 1). 
Ikram Masmoudi interesuje zatem to, w jaki sposób iraccy pisarze ukazują w swoich powieściach postawy jednostek wobec wojny i suwerennej władzy, z jakiej perspektywy rejestrują współczesną historię oraz jak w tych utworach wygląda „nowy Irak” z okresu po amerykańskiej inwazji (tamże).

W analizie irackiej fikcji literackiej autorka książki odwołuje się do rozważań Michela Foucaulta, poświęconych strukturze nowoczesnej władzy i biowładzy oraz do stworzonej przez Giorgio Agambena koncepcji homo sacer. Koncepcja ta staje się dla Masmoudi kluczowym narzędziem interpretacji wybranych utworów literackich, wykorzystywanym przez nią konsekwentnie $\mathrm{w}$ kolejnych rozdziałach pracy. Jak tłumaczy autorka za Agambenem, homo sacer to postać podwójnie wykluczona, pozbawiona zarówno praw boskich, jak i ludzkich; to nosiciel „nagiego życia” wystawiony na działanie suwerennej władzy i stosowanej przez nią przemocy w warunkach wprowadzonego przez nią stanu wyjątkowego; to człowiek przeklęty, wygnany poza nawias społeczności, którego można bezkarnie zabić. Agamben w traktacie Homo sacer. Suwerenna władza i nagie życie dowodzi, że do tego typu wykluczenia dochodzi w każdym czasie i w każdej kulturze, czy to w starożytnym Rzymie, czy w nazistowskim obozie koncentracyjnym. Masmoudi zwraca uwagę na funkcjonowanie kategorii homines sacres we współczesnym świecie w kontekście prowadzonych przez różne suwerenne władze wojen, na przykład pod szyldem „wojny z terroryzmem”. Władze te, zawieszając działanie zwykłych praw, autoryzują w imieniu państwa wszelkie formy ich naruszeń, przyznając sobie przy tym licencję na zabijanie. W ten sposób liczba osób, których życie narażone jest na niebezpieczeństwo, a ich śmierć zostaje usprawiedliwiona w imię „wyższych racji”, obejmuje między innymi uchodźców, więźniów, ludzi osadzonych w obozach, bojowników, dezerterów i jeńców wojennych. Obecność tych trzech ostatnich kategorii homines sacres autorka dostrzega na kartach najnowszych irackich utworów literackich (tamże: 3-7).

We wprowadzeniu do War and Occupation in Iraqi Fiction Masmoudi nie tylko wyraźnie nakreśla swoje zaplecze metodologiczne, lecz i omawia pokrótce specyfikę współczesnej irackiej fikcji literackiej, stanowiącej od samego początku swojego formowania (lata 20. XX wieku) komentarz do politycznych i społecznych wydarzeń; opisuje również fazy jej rozwoju. Autorka skupia się zwłaszcza na podejmujących tematykę wojny powieściach pióra pisarzy żyjących w Iraku w czasach rządów Partii Baas w latach 80. XX wieku, którzy zostali postawieni wobec dylematu: tworzenia utworów zgodnych $\mathrm{z}$ wymogami propagandy lub stosowania autocenzury; na wojennych powie- 
ściach irackich pisarzy emigracyjnych z lat 90. minionego stulecia, którzy w otwarty sposób pisali o cierpieniach Irakijczyków w kraju rządzonym przez dyktatora; wreszcie na podejmujących tematykę wojny powieściach opublikowanych $\mathrm{w}$ ostatnich latach (tamże: 7-18). Masmoudi przeznacza tu ponadto trochę miejsca, by przyjrzeć się powieściom irackich pisarek, które „świadczą o historycznym zadaniu i kulturowej roli, jaką kobiety odgrywają w zapisywaniu powiązanych ze sobą historii: ich własnych prywatnych historii i współczesnej historii ich kraju" (tamże: 18-19). Jednakże ostatecznie autorka wybiera do analizy, z dwoma wyjątkami, przede wszystkim utwory napisane przez mężczyzn, w których głównymi bohaterami stają się: dezerter wojenny, bojownik, zamachowiecsamobójca oraz człowiek osadzony w obozie, jako różne wcielenia homo sacer (tamże: 19-20)․․

Masmoudi zawęża wybór opublikowanych po 2003 roku powieści do dziesięciu uznanych przez nią za reprezentatywne, gdyż niektóre z nich przedstawiają wydarzenia wojny iracko-irańskiej (1980-1988), inne przybliżają sceny z I wojny w Zatoce Perskiej (1990-1991), jeszcze inne zaś obrazują amerykańską ofensywę na Irak i okres okupacji (2003-2011); są wśród nich wreszcie takie, które opowiadają o życiu bohaterów uczestniczących w kilku z wyżej wymienionych zbrojnych konfliktów. Reprezentatywność tych powieści jest także skutkiem osobistych doświadczeń ich autorów - emigrantów, byłych żołnierzy i dezerterów (tamże: 20-22).

Zasadniczą część książki Masmoudi podzieliła na cztery rozdziały ułożone $\mathrm{w}$ kolejności chronologicznej, zgodnie $\mathrm{z}$ następowaniem po sobie wspomnianych konfliktów. Jednocześnie w każdym z rozdziałów autorka koncentruje się na analizie jednej ze zdefiniowanych we wprowadzeniu literackich postaci homines sacres (dezerter wojenny, żołnierz, zamachowiec-samobójca, człowiek osadzony w obozie). Taka struktura pracy ma ukazać istnienie kontinuum $\mathrm{w}$ dewaluacji ludzkiego życia oraz tworzenia „nagiego życia” od czasów rządów Partii Baas aż po amerykańską okupację (tamże: 22).

\footnotetext{
${ }^{1}$ Autorka w dalszym fragmencie tekstu tłumaczy, że przewaga powieści autorstwa mężczyzn nie wynika $\mathrm{z}$ jej zamiaru, lecz jest podyktowana faktem, że większość utworów opisujących doświadczenia wojenne wyszła spod pióra pisarzy, którzy nierzadko opierali ich treść na osobistych przeżyciach (tamże: 21). Na marginesie warto zaznaczyć, że istnieją opracowania poświęcone wojennym utworom arabskich pisarek, jak chociażby książka Miriam Cooke, w której znajduje się rozdział dotyczący twórczości literackiej Irakijek z lat 80. i 90. XX wieku. Por.: Cooke (1996: 220-266).
} 
W każdym rozdziale Masmoudi osadza analizę kilku powieści w historycznym i kulturowym kontekście danego konfliktu (np. reżimowa propaganda podczas wojny iracko-irańskiej, charakter działań wojennych Amerykanów podczas I wojny w Zatoce Perskiej), wyjaśniając $\mathrm{w}$ ten sposób, $\mathrm{z}$ jakiego typu presją polityczną i społeczną bohaterowie tych powieści muszą się zmierzyć. Jednocześnie autorka z dużą dozą erudycji odwołuje się do rozważań innych badaczy poświęconych (postmodernistycznym) wojnom oraz życiu na okupowanych terenach i w obozach (Jean Baudrillard, Eleine Scarry, Franz Fanon, Giorgio Agamben i inni).

W efekcie, moim zdaniem, Masmoudi osiąga cel, jaki sobie założyła. Ukazuje ona, w jaki sposób współcześni pisarze iraccy uzupełniają w omawianych utworach brakujący fragment puzzli wiedzy o irackim społeczeństwie i jego kulturze. Naświetlają oni bowiem różne wydarzenia składające się na najnowszą historię Iraku z nowej perspektywy, nieznanej przede wszystkim zagranicznym odbiorcom, zdanym na powszechny przekaz medialny. Taką nową perspektywą może być perspektywa irackiego dezertera, dla którego porzucenie wojennych okopów, w których znalazł się z przymusu, jest nie tyle aktem tchórzostwa, co znakiem oswobodzenia się z politycznego ucisku, bądź też perspektywa niewinnie aresztowanego Irakijczyka, poznającego paradoksalne znaczenie słowa „demokracja” w zlokalizowanym gdzieś na pustyni amerykańskim obozie.

\section{Bibliografia}

Agamben, Giorgio. 1998. Homo Sacer: Sovereign Power and Bare Life. Tłum. Daniel Heller-Roazen. Stanford: Stanford University Press.

Cooke, Miriam. 1996. Women and War Story. Berkeley: University of California Press.

Ghazoul, Ferial J. 2009. Editorial. Literature and the Arts in Contemporary Iraqi Culture, International Journal of Contemporary Iraqi Studies 3, 3 (2009), 233-236. 